\title{
The New Competitive Advantage: Technological Change: An Application of Electronic Data Interchange Implementation in SME in Automotive Industry
}

\author{
Asli Goksoy (Corresponding author) \\ Department of Business, American University in Bulgaria \\ 1 Georgi Izmirliev Square, Blagoevgrad 2700, Bulgaria \\ Tel: (Turkey) 90-533-272-7388, (Sofia) 359-892-492-091Ｅ-mail: agoksoy@aubg.bg \\ Ozalp Vayvay \\ Department of Industrial Engineering, Faculty of Engineering \\ Marmara University, Goztepe, Istanbul, Turkey \\ E-mail: ozalp@marmara.edu.tr \\ Gülnur Karabulut \\ Birinci Otomotiv, Istanbul, Turkey \\ E-mail: gulnurk@birinciotomotiv.com.tr
}

Received: August 1, 2012

Accepted: September 12, 2012

Online Published: October 26, 2012

doi:10.5430/ijba.v3n6p25

URL: http://dx.doi.org/10.5430/ijba.v3n6p25

\begin{abstract}
The pace of change in technology has accelerated rapidly in the past decade providing various opportunities to companies to improve their efficiency and competitiveness. One of the useful and cost effective technological innovation is electronic data interchange (EDI). EDI has being increasingly used in many industries, as companies realized the potential benefits and competitive advantages of adopting electronic data exchange in their operations. EDI is strategically important, because good information systems are critical to the survival of many organizations. This paper presents an application of EDI in a SME in automotive industry in Turkey. With this study, our aim is to show the benefits of using EDI applications, explain how companies easily implement EDI in their system and what the advantages of these applications are.
\end{abstract}

Keywords: Technological change, Electronic data interchange (EDI), Competitive advantage, Automotive industry

\section{Introduction}

Technology will make collaboration companies' next competitive advantage. New tools are changing the way people work with each other, their companies' partners, and their customers (Rayport, 2011). We live in an era of risk and instability. Globalization, new technologies, and greater transparency have combined to upend the business environment and give many CEOs a deep sense of unease (Reeves \& Deimler, 2011).

Today's knowledge economy is marked by technological revolution and economic globalization (Hitt, 1998) resulting in rapid and continuous change, diminished product lifecycles and the need to turn large amounts of data into useable information (Ireland \& Hitt, 1999). Organizations have to be innovative and technology oriented in order to survive in the hypercompetitive business environment by sustaining a competitive advantage.

The twenty-first century is characterized by many, rapid changes (Toffler, 1970). In an organizational environment, these changes effect the need for the organization to adapt itself to the demands of the environment and make internal structural and cultural changes (Hanna, 2003). The changes in the world are many and various. Technological developments are among the most important ones with the broadest influence on organizations and their environment. The role of technology in the organizational world is complex and significant because it has a role 
both as a creator of change and as a tool for dealing with change, sometimes simultaneously (Shoham \& Perry, 2009). As firms change what they are and what they offer through the continuous morphing process, they migrate into a new strategic and competitive domains. This requires an inherent flexibility of the resources available, including IT resources, to a firm and its flexibility in applying those resources (Nkoyock, 2009).

Electronic data interchange (EDI) has been a useful technological innovation and became very popular in 1990s and 2000s. EDI can be defined as "the computer to computer exchange of business information electronically, in a structured format, between business trading partners." (Ferguson et al., 1990). For over two decades, electronic data interchange (EDI) has been one of the primary enabling technologies for conducting business-to-business (B2B) transactions and while the economics associated with EDI has long been a concern for many companies, the arrival of the Internet has made the technology feasible even for small firms (Narayanan et al., 2009). EDI-based transactions enabled more than $\$ 2$ trillion of trade among various firms in 2001 , with as many as $55 \%$ of all North American large and mid-size companies reporting the use of an EDI network (Kanakamedala et al., 2003). International Data Corporation (IDC) estimated the total value of EDI-traditional and Internet-grew from \$1.99 trillion in 2003 to $\$ 2.68$ trillion in 2007 (IDC, 2004). Also, the main reasons of its rapidly increasing diffusion are streamlining business processes and saving time to gain a competitive edge (Porter \& Millar, 1985).

The effective use of EDI has been studied in several operational contexts. Using EDI, the information interchanged is very widely, covering from sales (tracking back any purchase order), to financing and accountability (notifications of payments and rejected demands for payment) passing thought inventory control (product planning). For example, the objectives of all EDI systems is to improve the efficiency of the company by minimizing some of the most common problems associated to the supply chain management (out of stock, low inventories, achieve a certain product rotation...) (Jimenez \& Munoz, 2006). Many inter-organizational systems are increasingly using electronic data interchange to support the strategic supply chain by way of delivering and processing business documents. EDI can also provide many benefits to both organizations in a vendor-customer relationship (Lim \& Palvia, 2001). EDI can have significant bearing on customer service. EDI falls within the area of information and communication technology (Jimenez-Martinez \& Polo-Redondor, 1998). EDI provides a faster, more accurate, and less costly method of communication with customers compared to other methods (Crum et al., 1998). In other cases, it can be used in inventory control. Banerjee and Banerjee (1992) use economic order quantity based formulations to illustrate the coordination benefits made possible via EDI-based communications.

EDI is strategically important, because good information systems are critical to the survival of many organizations. It provide a competitive advantage to companies especially in manufacturing, trading and logistics sectors. For example, many international freight forwarders have chosen to differentiate themselves through development of sophisticated information management systems, particularly with respect to EDI. The development of these information management systems is crucial to the future existence of many international freight forwarders (Murphy \& Daley, 1996). Today's organizations are challenged by flexible manufacturing, reduced lead times, just-in-time production, and increased transportation volumes. This adds coordination complexity, and increases transaction costs. EDI improves the control of intra- and interorganizational transactions are in great demand. This is a great proof of EDI being established as a critical component in the infrastructure for electronic trading (Kumar \& Van Dissel, 1996).

From a different perspective, EDI is a necessary ingredient for the development of agile and virtual manufacturing processes. "agility" refers to the ability of a company to quickly respond to new business opportunities. In many cases a company cannot be agile unless it is part of a "virtual enterprise". By promoting EDI, one is helping business to build on its strengths in pursuit of increased competitiveness through agile and virtual business arrangements (Morell, 1995).

Academicians and practitioners do not have a fully developed international dimension in the theories of technological change, as well as a growing awareness of significant changes in the development of new technologies and in the production of goods and services. This has given rise to scholarship that ties together the international and domestic arenas to explain technological change (Breznitz, 2009).

Contrary to large companies, Small and Medium-size Enterprises (SME) have always demonstrated enormous reluctance to invest on EDI probably based on excessive investment costs when compared to the perceived benefits (Mira da Silva, 2003). While complexity and expense are commonly cited as the reasons for the lackluster diffusion of EDI, formal studies that examine factors responsible for successful EDI implementation are lacking (Angeles et al., 2001). Lastly, practitioners and academics agree that EDI is an important and beneficial interorganizational communication technology. Ahmad and Schroeder (2001, p. 16) summarize the state of academic research on EDI 
and note: "Even after more than 25 years of use of EDI in various industries, the literature is still inconclusive regarding the benefits gained from its usage." From these points of views, we believe this study is timely and important because it contributes to the existing literature with a solid, successful example in a SME which operates in a highly technology oriented and competitive industry. It is also important to point out the importance of EDI, as EDI is proven to be powerful innovation for improving business processes. The importance of EDI will grow in the future because it can help in major transitions that are going on especially in manufacturing: smaller, but deeper supply bases, more value added activity contracted to suppliers, shorter product life-cycles, agile manufacturing, and network based bidding/contracting procedures (Morell, 1995).

\section{Literature Review}

\subsection{Technological Change}

In recent times, technology has become an ever increasing presence in the workplace and it is one of the hot topics in business. More and more businesses, large and small, are trying to incorporate the latest technology into their operations. This notion is evidenced by the fact that the popular business publications now have technology sections, and information systems departments are becoming critical components of most organizations (Kiernan, 1995). The state of technology in any organization has a significant influence on the quality and quantity of production of its goods or services. But despite this, technology is prone to constant change which organizations have to monitor, manage and cope with. Especially, manufacturing industry that will like to be competitive and profitable should ensure that employees are trained and involved in the management of technological change for organizational survival (Dauda \& Akingbade, 2011).

Technology is a combination of theoretical-empirical knowledge that is used in the production and marketing of goods and services, which can be incorporated into the production team or which can become embedded as professional experience or as abilities and knowledge applied to the running of the business (Forman, 1982). Technological change refers to the development of an organization's technology over time. In general, two types of technological change have been identified in the literature: continuous or incremental change and discontinuous or breakthrough change (Zyclidopoulos, 1999).

Rapid technological innovation is another force for change in organizations, and those who fail to keep pace can quickly fall behind. Technological innovations bring about profound change because they are not just changes in the way work is performed. Instead, the innovation process promotes associated changes in work relationships and organizational structures. The variables used to measure the technological change in the organization are as follows: (1) implementation of the advanced technology, (2) learning new skills to use the technology, (3) periodic technology up gradation and, (4) teaching the technology to subordinates (Anjani \& Dhanapal, 2011).

Technological change is creating new business models that incorporate continuous change as a strategy (Geroski, 2000). This doesn't merely imply having a web page or a computer expert; for changes are much more profound, taking place throughout all working processes and affecting each department in firms (Perez, 2012). For example, understanding technological innovation is vital for marketing department for several reasons. Technological change is perhaps the most powerful engine of growth for them because it fuels the growth of new brands, creates new growth markets, and transforms small outsiders into market leaders (Chandy \& Tellis, 1998; Christensen, 1997). The bottom line is that technological change is considered as one of the main factors of productivity growth.

The introduction of new technologies has become critical for the maintenance and improvement of organizational competitive advantages (Bolívar-Ramos et al., 2011). Strategically, any technological change can be conducted to achieve specific objectives, with the ultimate goal to raise the competitive positioning of the enterprise. Also, the directions of the technological strategy and technological changes are much guided by the stage of the product's life cycle, by the conception of the dominant project, and by the technological trajectory of the enterprise, considering its restrictions (Utterback, 1994). New technologies enable organizations to develop products or delivery of services more quickly in highly competitive situations on a global level, as well as continuous technological change and ever shorter product life cycles (García et al., 2007).

Technological change can be radical. It can involve a shift to an entirely new technological trajectory that promises a superior price/performance frontier for the products in an industry (Gatignon et al., 2002; Dahlin \& Behrens, 2005). Technological change often necessitates change in firms' knowledge and capabilities (Helfat, 2000) and, as such, provides an ideal setting for considering how the increased routinization arising from process management practices affects organizational response to change. Technological change can potentially affect firm capabilities, because it 
introduces new scientific knowledge and generates new alternatives for configuring capabilities, performing organizational activities, and creating value (Lavie, 2006).

\subsection{Electronic Data Interchange (EDI)}

Because of its longevity, EDI has sparked the interest of researchers from nearly all the management disciplines, including operations management, purchasing, logistics, marketing, information systems and economics, strategic management, organizational behavior, and accounting/financial management. Each discipline has studied the role of EDI from its own perspective, using different theoretical foundations, research designs, and methodologies (Narayanan et al., 2009).

Electronic data interchange (EDI) has revolutionized the way in which organizations conduct their activities. The rapid growth of electronic commerce (e-commerce) in the global scope is forcing developing countries to adopt EDI to fulfill international electronic business-to-business (B2B) trades (Gibbs et al., 2003). EDI technology is presently utilized by tens of thousands of big companies all over the world for everyday electronic interchange of documents with their business partners, banking houses, state administration, customs authorities and other subjects involved in business (Vlckova, 2006). EDI is a key application powering e-business as according to Gartner Group; nearly 200,000 firms worldwide are using EDI as a part of their e-business initiative (Payne \& Simmons, 2000). Electronic data interchange (EDI) has revolutionized the way in which organizations conduct their activities. The rapid growth of electronic commerce (e-commerce) in the global scope is forcing developing countries such as China to adopt EDI to fulfill international electronic business-to-business (B2B) trades (Gibbs et al., 2003).

In recent years, several EDI studies intended to investigate the factors affecting EDI use (e.g., Sanchez \& Perez, 2005), and adoption intention (Teo et al., 2003). Albrecht and his colleagues (2005) examine EDI as one type of EC architectures in terms of marketplace and technology standards for B2B e-commerce. EDI can still remain the most vibrant IOS technology for business-to-business (B2B) electronic transactions with the emergence of the Web-based platform (Down, 2002). While many believe that EDI has moved towards online B2B exchanges, or a more open infrastructure such as XML (extensible markup language) which is touted as a more flexible and less expensive successor to EDI, a number of reports indicate that a majority of B2B electronic transactions are currently exchanged via EDI over a third-party value-added network or the Internet (Son et al., 2005).

The National Institute of Standards and Technology in a 1996 publication defines electronic data interchange as "the computer-to-computer interchange of strictly formatted messages that represent documents other than monetary instruments". Crum and his colleagues (1998) describe EDI as "the direct computer-to-computer communication of intercompany and intra-company business documents in a machine-readable standard format". EDI implies a sequence of messages between two parties, either of whom may serve as originator or recipient. The formatted data representing the documents may be transmitted from originator to recipient via telecommunications or physically transported on electronic storage media (Kantor \& Burrows, 1996).

EDI involves three very different and distinct disciplines. First, there has to be a business process. If the business process would be improved by being accomplished more quickly and with increased efficiency, then the business process is a candidate for EDI. The business process is the domain of the business functional area. Second, once the business process has been identified, data processing technologies have to be applied to the business process so that the process can be handled using computers. Some type of standard must come into play in the automation process so that paper documents that are the output of the business process can be put into a format that is interchangeable between computers. The automation of the business process is the domain of the data processing discipline. Third, the standardized business form must be transmitted from and received by computers, using data communications technologies. The data communications aspect of EDI is the domain of the data communications discipline (Copeland \& Hwang, 1997).

Among the many benefits of EDI are faster processing speed, greater accuracy, reduced costs [specifically the reduction of document processing costs and data reentry costs (Scala \& McGrath, 1993)], competitive advantage, improved operations, security, tracking and control, intra and inter company communications, and customer service (Craig, 1989; Mele, 1999). Other benefits that emerge from using EDI to solve discrete problems, such as error reduction in purchase orders, more accurate notification of the arrival of shipments, and reducing the need for labor by clerical personnel or buyers. The use of EDI is believed to strengthen the existing buyer-seller relationships (Marcussen, 1996). In other words, EDI generates money in that it tightens the relations between business partners and aids to increase the volume of business transactions. EDI supports the competitive advantage in that it allows more reasonable utilization of human potential, it economizes the operating costs, and it increases flexibility of work and promptness (Holan, 2005; Fellenstein \&Wood, 2000). 
Despite many benefits, the widespread adoption of EDI has been cumbersome: It has been too costly to implement, and the skills to design and operate EDI have been scarce (Krcmar et al., 1995). Other barriers relate to the nature of EDI: EDI creates network externalities, depends on an advanced information technology (IT) infrastructure, and relies on interorganizational standards (Damsgaard \& Lyytinen, 2001). The other main factors hindering implementation of EDI are organizational resistance to change, lack of standards, and lack of third party network support, high costs (hardware and software), security problems, and lack of control and transaction auditing (Principe, 2000).

Electronic data interchange is important because of its ability to contribute improvements to that information flow. Because companies are working at decreasing the number of their direct suppliers, more and more complex information will have to pass across organizational boundaries (Morell, 1995). Organizations first adopt EDI technology and then attempt to increase its use in order to derive financial benefits (Iacovou et al., 1995) or competitive advantage (Kumar \& Crook, 1996). Also, integration of EDI with other applications can be useful and beneficial. Integration of EDI with other applications could be organization-initiated or customer-initiated and involve process reengineering for the organization. Perceived benefits and costs of integration, as well as contextual factors such as organization size, IT capability, management support, and use of EDI in the industry are likely to be important determinants of EDI integration. Integration could lead to organizational benefits such as improved financial performance, improved customer service and development of new products and services (Crook \& Kumar, 1998).

The companies which heavily use EDI systems have the following characteristics: (1) organizational structure is decentralized, (2) EDI standards are compatible with those of trading partners, (3) EDI systems have greater compatibility with previously adopted systems or EDI systems have high compatibility with existing systems, (4) technical support from EDI vendors is strong, (5) education and training on EDI is provided consistently, (6) there exists strong trading partners' participation during EDI implementation, (7) formalization of the organization is high, (8) EDI user involvement is high and, (9) participation from trading partners is high during EDI implementation processes (Kim \& Lee, 2008).

\section{Case Study: EDI Implementation in a SME in Automotive Industry in Turkey}

The research framework is an attempt to investigate how EDI is implemented and used in a private company. The information given here has been obtained from the interviews conducted with the company personnel and from the company's website.

\subsection{Company Overview}

Birinci Otomotiv Sanayi Tic. A.Ş. (BOS) was founded in early 1970s in Istanbul, Turkey. The company started business by machining for casting and forging companies as a Tier 2 supplier. In 1988, the company started to forge fasteners and since then, it improved the capacity not only for machining, but also for forging. As a result, current forging capacity has become 8,000 tons a year. Since 1994, the company has been exporting and currently $45 \%$ of sales are generated by exports. Mainly exported countries are located in Eastern Europe (UK, Italy, Germany, Sweden, and Spain), Western Europe (Poland, Czech Republic, and Romania), China and Israel. The company is serving to different industries such as automotive, construction, military, energy and material handling with about 600 different parts.

Automotive is the most important sector for the company and its share is quite more than their competitors. The company produces special forging and machining parts for the passenger and commercial vehicles. Currently domestic market share is $55 \%$ and the main customer is Ford Otosan in Turkey.

\subsection{Company's Technological Change Strategies}

Producing products and services in this company have been managed by the systematic applications though different types of technology. In order to keep their competitive advantage among their competitors, Birinci Otomotiv values high quality. They follow technological innovation and improvements closely; therefore, they are able to lower production costs, while optimizing their product and service quality. They constantly update their systems and use the latest designs of machine and equipment. Lastly, they attend international trade shows to follow the recent developments in technology.

\subsection{Internal Communication Method in the Company}

Like most of the companies, Birinci Otomotiv has integrated software for the internal communication. This system is called System 1 and it was implemented by the company's own IT department. By Via System 1, all departments can 
enter data, trace and process them and all activities are carried out with this system. Furthermore this system is adapted to EDI. Exchanged documents between supplier-customer are inquiry form, quotation form, purchase order, delivery schedule, shipment document (packing list, advance shipping notice), invoice, design, drawing specifications, and CAD data.

\subsection{Exchange Activities before EDI Application}

\subsubsection{Order Reception \& Processing}

The orders and delivery schedules are received by e-mail/fax from many customers. The process steps are as following: (1) customer purchase orders are received by e-mail or fax, (2) the orders are entered into the system manually by sales department, (3) the production planning department sees the orders in the system and process the BOM and show all requirements (purchased material, raw-material, etc.), (4) the machine loadings are made by planning department considering the required delivery date, (5) the purchasing department meets all requirements within the required date and, (6) production department is responsible for the daily production orders.

There are some restrictions as process steps are made manually. In case of any error on the fax or e-mail, data will not be processed on time and finally causing the supply issues and customer dissatisfaction. In case responsible person enters the wrong data (wrong quantity, delivery date, part number, etc.) in the system, the result will be ineffective.

Email messages "arrive when they arrive" and there is no way to know if they have already arrived at the destination. Many email messages are returned with errors to the sender (sometimes 5 days later!) and some just disappear. In fact, since email messages can arrive many days after being sent, one never knows if the message will arrive one day.

\subsubsection{Shipment Document Processing}

When the parts are ready to be shipped, it is necessary to prepare shipment documents in the system and share this information with the trading partner in advance to delivery. In case this information is not given to customer; it causes delays on booking the goods on time, not being aware of the quantity on transit, and delay on the payments. The shipment processing steps in the company are as following: (1) as soon as the parts are packaged; the shipment notices are prepared by the logistic department, (2) in case the customers are located in abroad, the export documents are prepared both by logistic and accounting department to give to the customs agency and, (3) the delivery notes and invoices are sent to customer via fax/e-mail to inform the customer about the shipment.

\subsubsection{Inquiry, Drawing, 3D Data Reception and Processing}

Before e-commerce implementation, the company receives the related data by e-mail /fax. Generally it is easy to get the drawings by e-mail/ fax, however for 3D data, using email/ fax is not an effective communication channel to use. 3D data can never be received by fax and furthermore sometimes that is not achievable to receive 3D data by email because of the size.

\subsection{The History of the EDI Implementation in the Company}

The company had no experience for EDI applications until their biggest customer; Ford obligated all Tier 1 suppliers to implement EDI connection. As a result, Birinci's EDI adventure started in 2006. EDI requirement are followed by other customers such as Audi \& VW, Jaguar \& Land Rover, Vibracoustic, Dana, and Mercedes within the following years.

\subsubsection{EDI Types Used in the Company}

There are many ways for EDI implementation and the company should decide to use the most suitable one for each customer. In implementation stage; the most important criteria to choose the best option are as following: customer requirements, cost of the application and ease of the use.

The most important selection criterion is customer requirement. If the customer obligates to use one type of EDI, there is no other way, but to implement it. Also, if the customer requirements are not fully met with other types of applications, the company must implement the specified EDI types. In this case study, we see that the company used different application types because of the customer requirements.

If the company is free to use any type of EDI application, then the second criteria, the cost of implementation is to be considered during set-up and lifetime. In that case WebEDI is the best solution as there is no set-up cost and just need internet line and computer. 


\subsubsection{EDI Document Standards}

As EDI implementation is fully depend on customer requirements, the document types must also be selected conform to customer document standard. The company is not free to select to use its own document standard. With all customers, company use VDA types of EDI documents.

\subsection{General EDI Applications with Customers}

\subsubsection{EDI Applications with Audi and VW}

Supplying just one part to Audi, the company started to use WebEDI with Audi AG via B2B portal (www.vwgroupsupply.com).

\subsubsection{System Requirements}

There are minimum requirements about hardware and software. In order to work in the WebEDI supplier platform, the company placed the below requirements on the hardware and software:

- A standard PC which should be equipped with at least 64MB RAM and $350 \mathrm{MHz}$ Graphic board and monitor should support a screen resolution of $1024 * 768$.

- Internet access

- An Internet browser. The system is optimized to the Internet-explorer, beginning with version $>=5.5$. But indeed, the browser must support a 128-Bit encoding.

For printing the delivery instruction data, accompanying documents and transport labels with barcode: A printer with a resolution of at least $300 \mathrm{dpi}$, laser printer recommended.

Second is about the access to the WebEDI supplier platform. The person should enter the address (www.vwgroupsupply.com) in the browser and confirm its entry with "enter". The display appears (Exhibit 1); to call for the actual application, "login" on the left side of the page is clicked (Exhibit 2). In order to get to the WebEDI application "logistics" in the drop-down menu is selected. In order to get to the application, underlined link "WebEDI" below the picture is clicked (Exhibit 3). With this application, the company is able to see and process the followings: daily call off (Exhibit 4) and forecast schedule, creating delivery instruction (Exhibit 5), creating label and creating transport.

\subsubsection{The Advantages of Using WebEDI with VW Group instead Classical Methods}

These are as follows:

-As soon as customer changes its demand, supplier is able to see these changes one day after this update on B2B portal.

-Supplier is able to process data via this system.

-Supplier can create Audi formatted label in B2B portal, instead of implementing software to create the VW standardized label.

-Supplier can create a transport documents via this system.

-Customers see what will be shipped as soon as supplier creates a transport.

-Suppliers see what was shipped and what was actually received by customers. No need for a call or e-mail in order to get information of the shipment status. As soon as the parcel is received, the cumulative receipt quantity is being updated in the B2B portal.

\subsubsection{EDI Applications with Jaguar and Land Rover}

The company supplies parts to JLR since 2008. It is a must for Tier 1 suppliers to use EDI in case there are more than four supplied production parts. If the supplied part quantity is less than five, then suppliers could also use eDDL (Electronic Direct Data Link) via portal Covisint. Until 2010, the company had only four references, therefore they just used eDDL; however, since 2010 the company works with GXS as an EDI Van.

\subsubsection{1 eDDL Access by Covisint}

The Covisint is a portal that most of the automotive manufacturers use it for communication with their suppliers. The companies who use Covisint for communication with their suppliers are Ford, Jaguar Land Rover, Daimler, GM, Delphi, JCI, Lear, Michigan, Mitsubishi and Visteon. 


\subsubsection{How to Use Covisint for Communication}

After entering the address (www.covisint.com) in the browser, a display appears (Exhibit 6). The username and password are entered and the "login" is clicked. After logged in, the supplier portal must be selected (Exhibit 7). From application link, the eDDL can be chosen and via user specific password the system can be used.

The benefits of eDDL system are being able to see the weekly call off (830), daily call off (862), the customer inventory, quantity on transit, delivery note (for example, ASN-advance shipping note), etc. on time of shipment.

3.6.3 Alternative EDI Application with Jaguar and Land Rover: EDI via VAN: GXS Trading Partner

GXS delivers global B2B e-commerce integration solutions to over 75 percent of Fortune 500 companies. Through the company's key offerings, GXS Trading Grid ${ }^{\circledR}$ and GXS Managed Services; they enable simplified document exchange, enhanced supply chain visibility and streamlined communications with their partners. The Jaguar and Land Rover pays to GXS for the implementation of EDI with their suppliers and it is free to use for the suppliers.

\subsubsection{How to Use EDI Application with GXS}

As soon as the set-ups are made, the GXS receive data from customer and send it to specified e-mail with a following notification:

\section{GXS Email Notification}

A new document has just arrived in your inbox.

Type of Document: DELJIT

Sender: JAGUAR LAND ROVER MS PRODUCTION

Receiver: BIRINCI OTOMOTIV SAN.TIC.AS

Date: Aug/10/2010 03:20 GMT

Version/release number: 1

Document Reference: OG\# 102210000420

You can access this document from your inbox on GXS at https://tradinggrid.gxs.com

The recipient sees the updated data in its mailbox (Exhibit 8).

When the document is selected, it can be downloaded in type of CVS, PDF or XML. Receiving the order, supplier can create shipment and delivery note, and then send it on time of delivery made.

\subsubsection{EDI Applications with Ford}

The first EDI implementation was started with Ford. The company use WebEDI for document translation and furthermore software was integrated to EDI to send delivery notes and receive the orders automatically. The orders are received in XML format and transferred into software, so that the complicated orders can be understood easily by all people.

\subsection{The Comparisons of Different EDI Types in the Company}

\subsubsection{WebEDI Advantages}

-There is no set-up cost and free to use, just need a computer and internet.

-It is easy to use by everyone, no need for a complicated course. No training or adaptation cost. The hotline services can support users by online training.

-The customer demands can be seen on time of the update. No need to wait to receive the order by fax, e-mail or post.

3.7.2 WebEDI Limitations

-Users need a User ID and password.

-Internet connection is required to connect the related portal.

-To update the supplier system is just depend on the user; therefore at least two users must be able to use the system in a company. 


\subsubsection{EDI via VAN Advantages}

- The VAN is a fundamental concept on traditional EDI in order to support asynchronous communication; otherwise all partners had to be connected all the time to all other partners

- A VAN provides some "added value" such as checking the message header and format and offering security, logging, archiving and auditing services.

-The set-up cost is cheaper or no set-up cost is required when compared with EDI with Software.

-The EDI messages are sent to user e-mail; therefore the user can be informed whenever there is an update on customer system. When compared to Web EDI, the system updates are more independent of the user.

-The VAN can translate the document types into whatever supplier needs. Trading partner can offer the documents alternatively in the user required format. Generally messages are sent in VDA or XML format and it is difficult for users to understand what the customer's exact requirements.

\subsubsection{EDI via VAN Limitations}

-Trading partners such as GXS, Map, etc. do not give their services free of charge to their users. Customer or supplier needs to pay in order to get this service.

-In case supplier has one or two parts and if the schedules are not updated frequently, it is not a good way to pay periodically for VAN service. The Web EDI or other types of communications should be preferred (i.e.: Covisint eDDL application, B2B portals).

-In case supplier has so much different types of products, EDI with software should be preferred method instead WebEDI or EDI via VAN. Because user has to transfer all data into its own software and it is time-consuming and error risk is on the high level.

\subsubsection{EDI with Software Advantages}

-The system automatically updates all data and users do not enter any data manually, time saving process.

-The customer standard automatically transferred into supplier standard and user is not confused with unknown data.

-No periodic payments to use the system.

\subsubsection{EDI with Software Limitations}

-Set-up and implementation costs are quite high when compared other EDI methods.

-User can ignore the customer changes, because system automatically updates the data.

-There must be IT people who are comply with the software, generally most of the SME cannot have IT people in their facility.

- Even converting the message is not trivial because there are many small details to deal with. For example, the product code in the message can be the EAN barcode but the ERP only accepts orders with their own internal code (Karabulut, 2011).

\section{Conclusion}

This case study summarizes a real-world experience in a SME where EDI applications have been implemented and used successfully. After EDI implementation, the company listed the benefits as: cost saving, time saving, increased efficiency, better communication, less error and delays. Consequently, customer satisfaction and performance level has been dramatically increased.

With this case study; we see that there are many ways for EDI implementation in a cost-saving and affordable way. The main important issues for SMEs are developing the suitable organizational environment for managing the EDI systems; choose the right EDI solution to meet the needs of the organization and related partners and obtain the support and commitment of top management, as implementation can be a long process. Also, we can offer some practical solutions to SMEs which are new beginners for EDI. For companies who do not want to invest on EDI, but EDI is a priority requirement for their customers, the first suggestion can be WebEDI. Because this type of EDI is free of charge to apply, more effective and easier than manual document exchanging, also more reliable. It provides a basic EDI experience to the users. On the other hand, this method is not fully automated system and effectiveness of the system is completely depending on the users.

Although there are sensible advantages of using EDI, the challenges should not be ignored. Unfortunately, most of the focus on EDI is concentrated on the technical details of exchanging messages between two partners, that is, how 
the large company sends orders to the SME and how the SME sends delivery notes/ invoices to the large company. Although this is an important issue for EDI adoption by SME, there are other many technical challenges that are worth discussing. (Mira da Silva, 2003). In this paper, we also tried to explain what kind of limitations/ challenges could occur for different types of EDI applications.

EDI is important because organizations are under relentless pressure to reduce costs, improve efficiency, and shorten the product life-cycle. EDI contributes to these efforts by speeding the flow of information, and by casting data in a form that is readily accessible for a wide variety of uses. For example, EDI reduces the likelihood of errors in manual data entry and thus eliminates the need for a variety of data quality checks. As a result of these capacities, EDI is also a powerful tool for improving business processes (Morell, 1995).

As the pace of globalization and social change quickens, executives are correctly calling for greater agility, flexibility and innovation from their companies. Largely ignored in these pleas, however, is the simple fact that organizations have been designed to seek sustainable competitive advantages and stability (Worley \& Lawler III, 2006); one good way is to design and implement successful change programs and also create an organizational culture which will foster and maintain a balance between stability and change in order to keep the competitive advantage gained through technology. As witnessed many times, technology advances have had extreme impacts in the workplace. In today's highly competitive business environment, organizations have to follow technological improvements, as changes and innovations in technology cause a tremendous paradigm shift in the way organizations do business. One thing is clear that for an organization to offer cost effective and compatible products and services, modern technology has to be employed and technological advancements have to be implemented. Managers must know what value new technologies can bring and how to link technological capabilities with the firm's basic competencies (Berry \& Taggart, 1998), enabling them to achieve considerable organizational advantages. Therefore, managers should stress the fostering of technology and organizational innovation, since they constitute strategic dynamic capacities that can have positive effects on improving organizational performance (Real et al., 2006).

Further research can focus on the EDI's positive impact on employees. As EDI saves times and reduce various costs in organizations, future research results may show increase in employee satisfaction and productivity after EDI implementation in a given organization. Also, EDI contributes to inter-industry growth. This can be another area to research. EDI technology and VANs will not become extinct soon, as EDI does well with supporting traditional electronic document exchange, therefore, it is worthwhile to invest in this topic.

\section{References}

Ahmad, S., \& Schroeder, R.G. (2001). The impact of electronic data interchange on delivery performance. Production and Operations Management, 10, 16-30. http://dx.doi.org/10.1111/j.1937-5956.2001.tb00065.x

Albrecht, C. C., Dean, D. L., \& Hansen, J. V. (2005). Marketplace and technology standards for B2B ecommerce: Progress, challenges, and the state of the art. Information and Management, 42, 865-875. http://dx.doi.org/10.1016/j.im.2004.09.003

Angeles, R. Corritore, C. L., Basu, S. C., \& Nath, R. (2001). Success factors for domestic and international electronic data interchange (EDI) implementation for US firms. International Journal of Information Management, 21, 329-347. http://dx.doi.org/10.1016/S0268-4012(01)00028-7

Anjani, P. K., \& Dhanapal, D. (2011). A study on the types of organizational change of the banking sector in Salem District. European Journal of Social Sciences, 25(1), 103-113.

Banerjee, A., \& Banerjee, S. (1992). Coordinated, orderless inventory replenishment from a single supplier and multiple buyers through electronic data interchange. International Journal of Technology Management, 7(4), 328-336.

Berry, M. M. J., \& Taggart, J. H. (1998). Combining technology and corporate strategy in small high tech firms. Research Policy, 26, 883-895. http://dx.doi.org/10.1016/S0048-7333(97)00064-4

Bolívar-Ramos, M. T., García-Morales, V. J., \& Mihi-Ramírez, A. (2011). Influence of technological distinctive competencies and organizational learning on organizational innovation to improve organizational performance. Economics and Management, 16, 670-675.

Breznitz, D. (2009). National institutions and the globalized political economy of technological change: an introduction. Review of Policy Research, 26(1-2), 1-12. http://dx.doi.org/10.1111/j.1541-1338.2008.00388.x

Chandy, R. K., \& Tellis, G. J. (1998). Organizing for radical product innovation: The overlooked role of willingness to cannibalize. Journal of Marketing Research, 35, 474-87. http://dx.doi.org/10.2307/3152166 
Christensen, C. M. (1992). Exploring the limits of the technology S-Curve, Part I: Component technologies. Production and Operations Management, 1(4), 334-57. http://dx.doi.org/10.1111/j.1937-5956.1992.tb00001.x

Copeland, K. W., \& Hwang, C. J. (1997). Electronic Data Interchange: Concepts and Effects. Internet Society's seventh annual conference (INET'97).

Craig, A. L. (1989). EDI increases productivity and competitiveness. Journal of Electronic Data Interchange, $133-137$.

Crook, C. W., \& Kumar, R. L. (1998). Electronic data interchange: a multi-industry investigation using grounded theory. Information \& Management, 34, 75-89. http://dx.doi.org/10.1016/S0378-7206(98)00040-8

Crum, M. R., Johnson, D. A., \& Allen, B. (1998). A longitudinal assessment of EDI use in the U.S. motor carrier industry. Transportation Journal, 38(1), 15-28.

Dahlin, K. B., \& Behrens, D. M. (2005). When is an invention really radical? Defining and measuring technological radicalness. Research Policy, 35, 717-34. http://dx.doi.org/10.1016/j.respol.2005.03.009

Damsgaard, J., \& Lyytinen, K. (2001). The role of intermediating institutions in the diffusion of electronic data interchange (EDI): How industry associations intervened in Denmark, Finland, and Hong Kong. The Information Society, 17, 195-210. http://dx.doi.org/10.1080/01972240152493056

Dauda, Y. A., \& Akingbade, W. A. (2011). Technological change and employee performance in selected manufacturing industry in Lagos state of Nigeria. Australian Journal of Business and Management Research, 1(5), $32-43$.

Down, A. (2002). Integrating EDI systems across and beyond your enterprise, IBM White Papers, Somers, NY. [Online] Available: www-3,ibm.com/software/integration/wdi/library/whitepapers/edi_vlc.pdf

Fellenstein, C., \& Wood, R. (2000). Exploring E-commerce, Global E-business and E-societies. Prentice-Hall, Inc.

Ferguson, D. M. Hill, N. C., \& Hansen, J. V. (1990). Electronic Data Interchange: Foundations and Survey Evidence on Current Use. Journal of Information Systems, 4, 81-91.

Forman, A. L. (1982). La tecnología como arma competitiva. Harvard-Deusto Business Review.

García, V. J., Ruiz, A., \& Lloréns, F. J. (2007). Effects of technology absorptive capacity and technology proactivity on organizational learning, innovation and performance: An empirical examination. Technology Analysis \& Strategic Management, 19, 527-558. http://dx.doi.org/10.1080/09537320701403540

Gatignon, H., Tushman, M., Smith, W., \& Anderson, P. (2002). A structural approach to assessing innovation. Management Science, 48, 1103-22. http://dx.doi.org/10.1287/mnsc.48.9.1103.174

Geroski, P. A. (2000). Models of technology diffusion. Research Policy, 29, 603-625. http://dx.doi.org/10.1016/S0048-7333(99)00092-X

Gibbs, J., Kraemer, K. L., \& Dedrick, J. (2003). Environment and policy factors shaping global e-commerce diffusion: a cross-country comparison. Information Society, 19(1), 5. http://dx.doi.org/10.1080/01972240309472

Hanna, D. E. (2003). Building a leadership vision: Eleven strategic challenges for higher education. Educause Review, 38(4), 25-34.

Helfat, C. E. (2000). Guest editor's introduction to the special issue: The evolution of firm capabilities. Strategic Management Journal, 21, 955-959. http://dx.doi.org/10.1002/1097-0266(200010/11)21:10/11<955::AID-SMJ136>3.0.CO;2-S

Hitt, M. A. (1998). Twenty-first-century organizations: Business firms, business schools and the academy. Academy of Management Review, 23(2), 218-224.

Holan, P. (2005). Communicate directly. Logistics Systems, 5(42), 22-23.

Iacovou, C. L., Benbasat, I., \& Dexter, A.S. (1995). Electronic data interchange and small organizations: Adoption and impact of technology, MIS Quarterly, 465-485. http://dx.doi.org/10.2307/249629

International Data Corporation. (2004). Worldwide traditional and Internet EDI commerce forecast, 2002-2007. Framingham, MA: Author.

Ireland, R. D., \& Hitt, M. A. (1999). Achieving and maintaining strategic competitiveness in the 21st century: The role of strategic leadership. Academy of Management Executive, 13(1), 43-57. 
Jimenez-Martinez, J., \& Polo-Redondo, Y. (1998). International diffusion of a new tool: the case of Electronic Data Interchange (EDI) in the retailing sector. Research Policy, 26, 811-827. http://dx.doi.org/10.1016/S0048-7333(97)00045-0

Jimenez, L., \& Munoz, R. (2006). Integration of supply chain management and logistics: development of an electronic data interchange for SAP servers. 16th European Symposium on Computer Aided Process Engineering and 9th International Symposium on Process Systems Engineering. 2201-2206. W. Marquardt, C. Pantelides (Editors), Published by Elsevier B.V. http://dx.doi.org/10.1016/S1570-7946(06)80375-5

Kanakamedala, K., King, J., \& Ramsdell, G. (2003). The truth about XML. McKinsey Quarterly, (3), 9-12.

Kantor, M., \& Burrows, J. H. (1996). Electronic Data Interchange (EDI). National Institute of Standards and Technology [Online] Available: http://www.itl.nist.gov/fipspubs/fip161-2.htm (July 14, 2012)

Karabulut, G. (2011). EDI applications in the automotive industry. Master Thesis. Maramra University, Institue for Graduate Studies in Pure and Applied Science, Istanbul, Turkey.

Kiernan, V. M. (1995). The impact of technology on organizational transformations. [Online] Available: http://www.mindspring.com/ kiernan/mgt6107.html (July 27, 2012)

Kim, B. G., \& Lee, S. (2008). Factors affecting the implementation of electronic data interchange in Korea. Computers in Human Behavior, 24, 263-283. http://dx.doi.org/10.1016/j.chb.2006.11.002

Krcmar, H., Bjørn-Andersen, N., \& O'Callaghan, R. (1995). EDI in Europe: How it works in practice. New York: JohnWiley \& Sons.

Kumar, K., \& Van Dissel, H. G. (1996). Sustainable collaboration: Managing conflict and cooperation in interorganizational systems. MIS Quarterly, 20(3), 279-300. http://dx.doi.org/10.2307/249657

Kumar, R., \& Crook, C. W. (1996). Educating senior management on the strategic benefits of EDI. Journal of System Management, 42-47.

Lavie, D. (2006). Capability reconfiguration: an analysis of incumbent responses to technological change. Academy of Management Review, 31(1), 153-174. http://dx.doi.org/10.5465/AMR.2006.19379629

Lim, D., \& Palvia, P. C. (2001). EDI in strategic supply chain: impact on customer service. International Journal of Information Management, 21, 193-211. http://dx.doi.org/10.1016/S0268-4012(01)00010-X

Marcussen, C. H. (1996). The effects of EDI on industrial buyer- seller relationships: A network perspective. International Journal of Purchasing and Materials Management, 20-26. http://dx.doi.org/10.1111/j.1745-493X.1996.tb00282.x

Mele, J. (1999). Simpler solutions. Fleet Owner, 94(1), 50-52.

Mira da Silva, M. (2003). Challenges for EDI adoption by small and medum-sze enterprises (SME). IADIS International Conference E-Society, 603-607.

Morell, J. A. (1995). Promoting electronic data interchange: building a foundation for support to small business. [Online] Available: http://www.jamorell.com/Jonny/web_new/EDI_survey/finalrpt.pdf (July 14, 2012)

Murphy, P. R., \& Daley, J. M. (1996). International freight forwarder perspectives on electronic data interchange and information management issues. Journal of Business Logistics, 17(1), 63.

Narayanan, S., Marucheck, A. S., \& Handfield, R. B. (2009). Electronic data interchange: Research review and future directions. Decision Sciences, 40(1), 121-163. http://dx.doi.org/10.1111/j.1540-5915.2008.00218.x

Nkoyock, A. (2009). Distributed knowledge. [Online] Available: http://blog.nkoyock.net/?m=200909 (July 26, 2012).

Payne, R., \& Simmons, C. (2000). Electronic data interchange (EDI): An overview. Gartner Group Strategy amd Tactics/Trends \& Direction, The Gartner Group Web Site. [Online] Available: http://www.gartnergroup.com

Perez, A. S. (2012). New technologies and their relationship with quality and human resources in the Spanish hotel industry. [Online] Available: www.uv.es (July 26, 2012)

Porter, M. E., \& Millar, V.E. (1985). How information gives you competitive advantage. Harvard Business Review, 85(4), 149-160.

Principe, J. (2000). Learn about the limitations of traditional EDI and why the future of networking lies in Internet EDI and XML. Purdue University Web site. [Online] Available: http://expert.cc.purdue.edu/Bjprince 
Rayport, J. F. (2011). Technology will make collaboration your next competitive advantage. [Online] Available: http://www.technologyreview.com (July 14, 2012)

Real, J. C., Leal, A., \& Roldán, J. L. (2006). Information technology as a determinant of organizational learning and technological distinctive competencies. Industrial Marketing Management, 35, 505-521. http://dx.doi.org/10.1016/j.indmarman.2005.05.004

Reeves, M., \& Deimler, M. (2011). Adaptability: The new competitive advantage. Harvard Business Review, 135-141.

Sanchez, A. M., \& Perez, M. P. (2005). EDI and the moderator effect of interorganizational cooperation in the supply chain. Journal of Organizational Computing and Electronic Commerce, 15(2), 83-104. http://dx.doi.org/10.1207/s15327744joce1502_1

Scala, S., \& McGrath, R. J. (1993). Advantages and disadvantages of electronic data interchange: An industry perspective. Information \& Management, 25(2), 85-91. http://dx.doi.org/10.1016/0378-7206(93)90050-4

Shoham, S., \& Perry, M. (2009). Knowledge management as a mechanism for technological and organizational change management in Israeli universities. High Education, 57, 227-246. http://dx.doi.org/10.1007/s10734-008-9148-y

Son, J. Y., Narasimhan, S., \& Riggins, F. J. (2005). Effects of relational factors and channel climate on EDI usage in the customer-supplier relationship. Journal of Management Information Systems, 22(1), 321-353.

Teo, H. H., Wei, K. K., \& Benbasat, I. (2003). Predictingintention to adopt interorganizational linkages: An institutional perspective. MIS Quarterly, 27(1), 19-49.

Toffler, A. (1970). Future shock. New York: Bantam Books.

Utterback, J. M. (1994). Mastering the Dynamics of Innovation. Harvard Business School Press, Boston, MA.

Vlckova, V. (2006). ERP and EDI system as tools for integrated logistical management support. VADYBA / Management, 1(10), 124-134.

Worley, C. G., \& Lawler III, E. E. (2006). Designing organizations that are built to change. MIT Sloan Management Review, 48(1), 19-23.

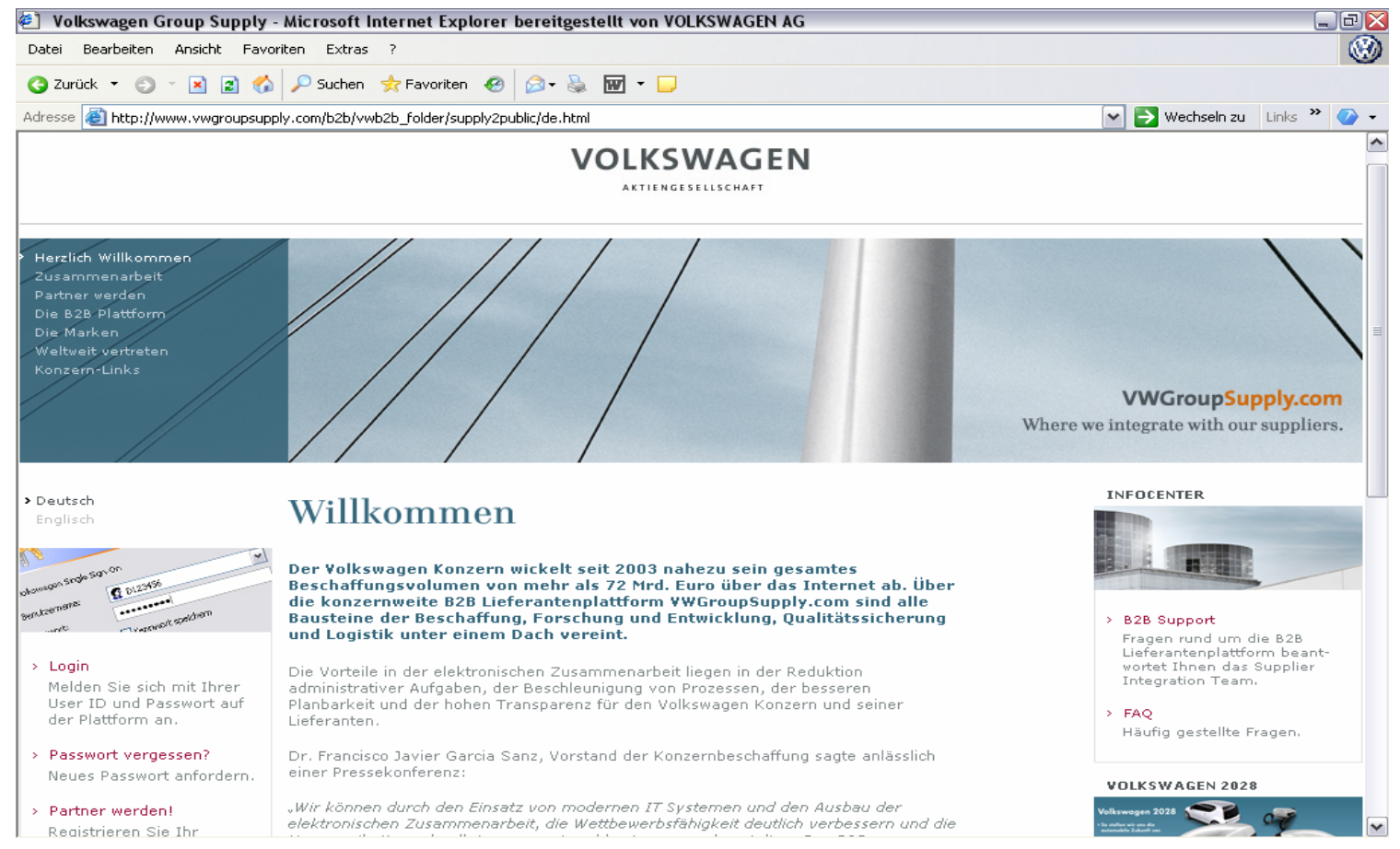

Exhibit 1 


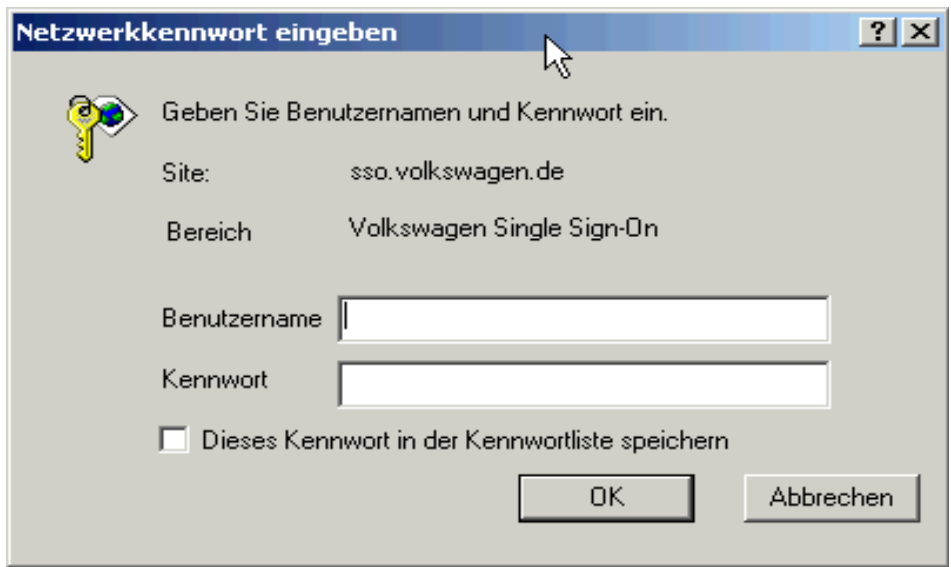

Exhibit 2

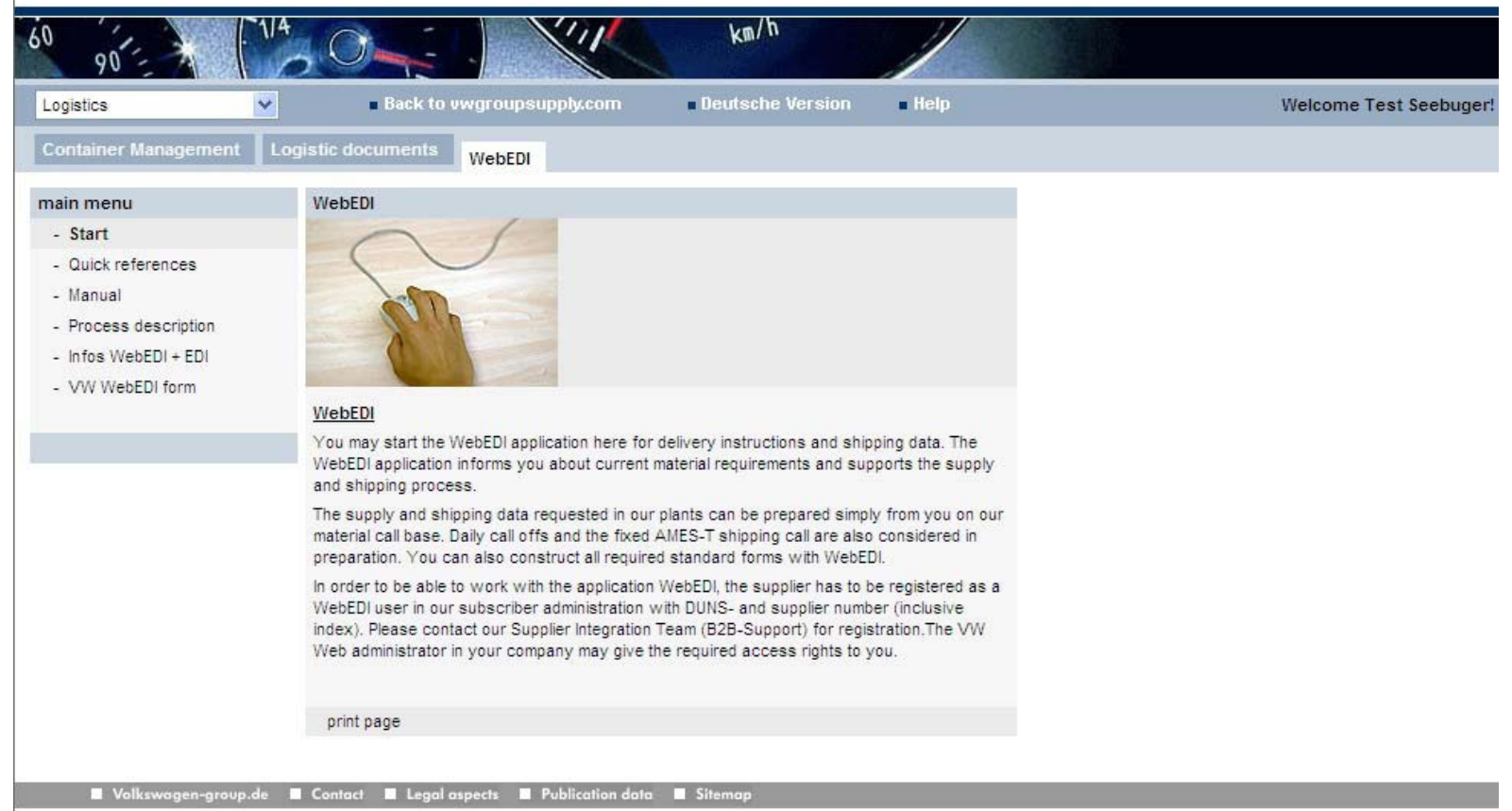

Exhibit 3 


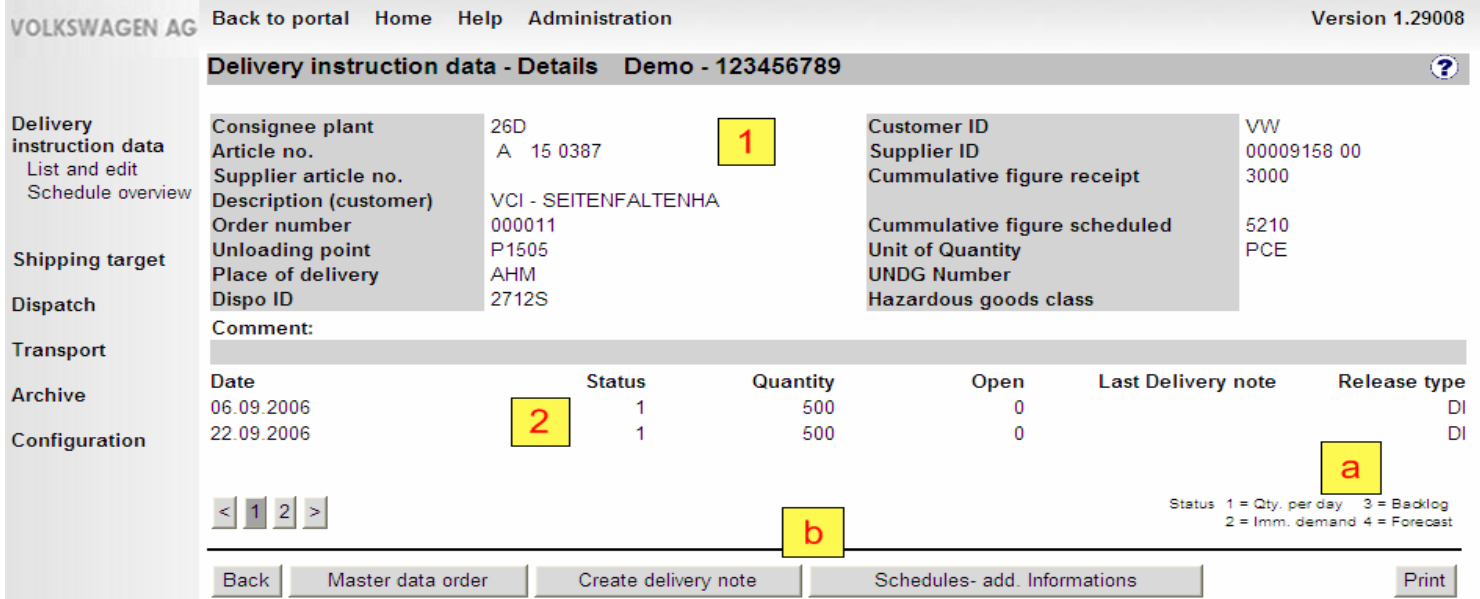

Exhibit 4

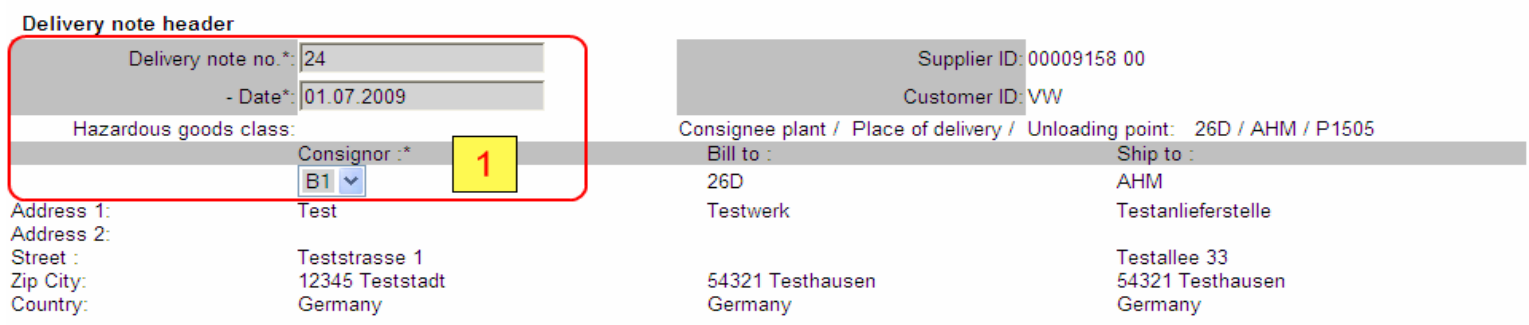

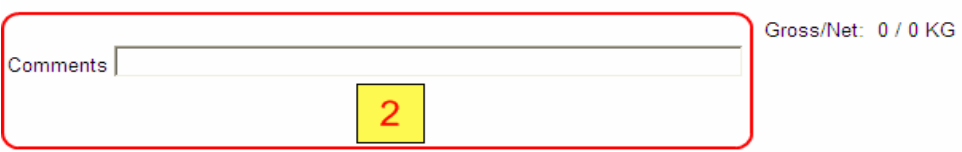

All fields marked by an asterisk ( $\left(^{\star}\right)$ must be filled!

Back Delivery line items a

\section{Exhibit 5}

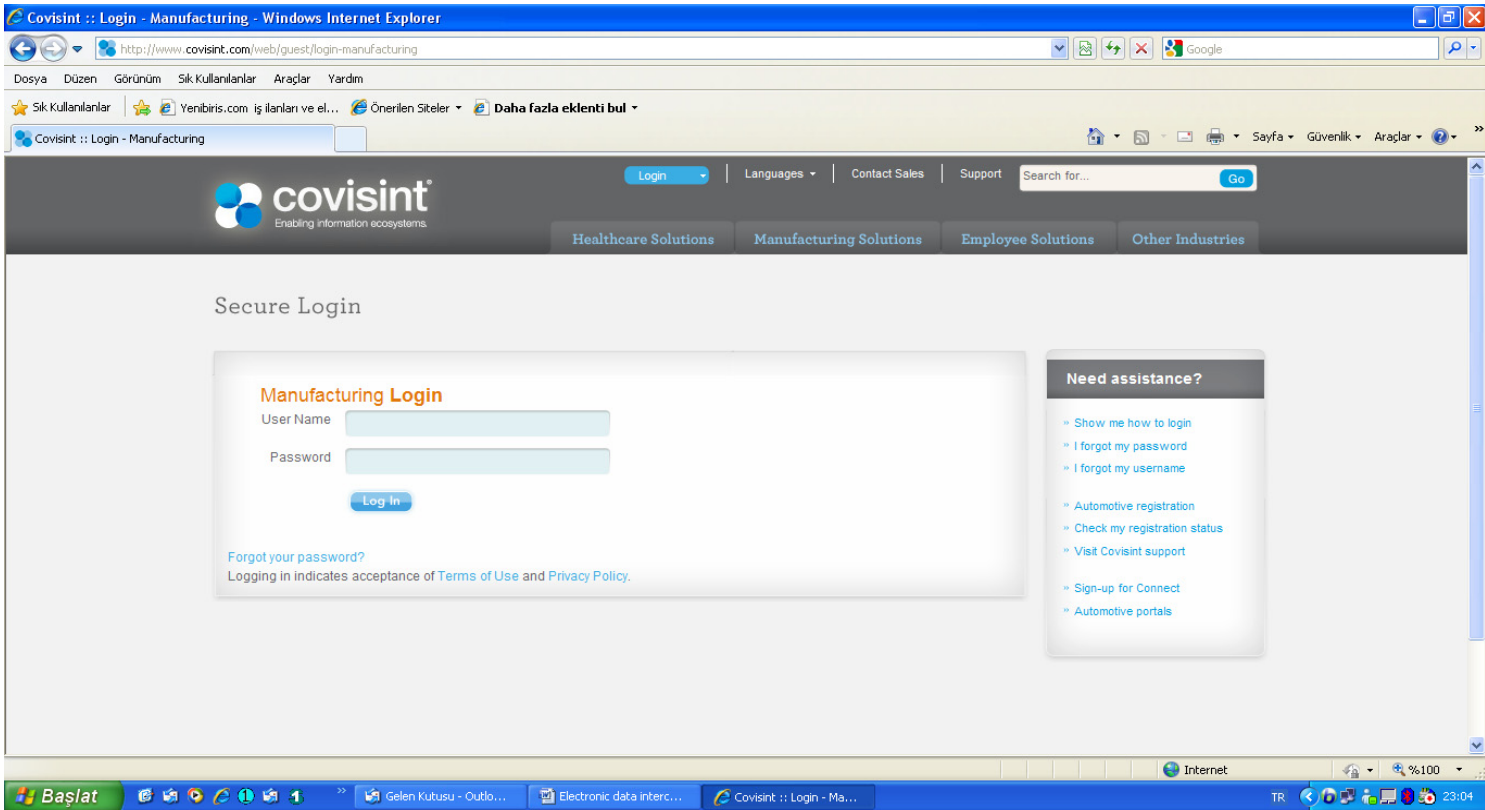

Exhibit 6 


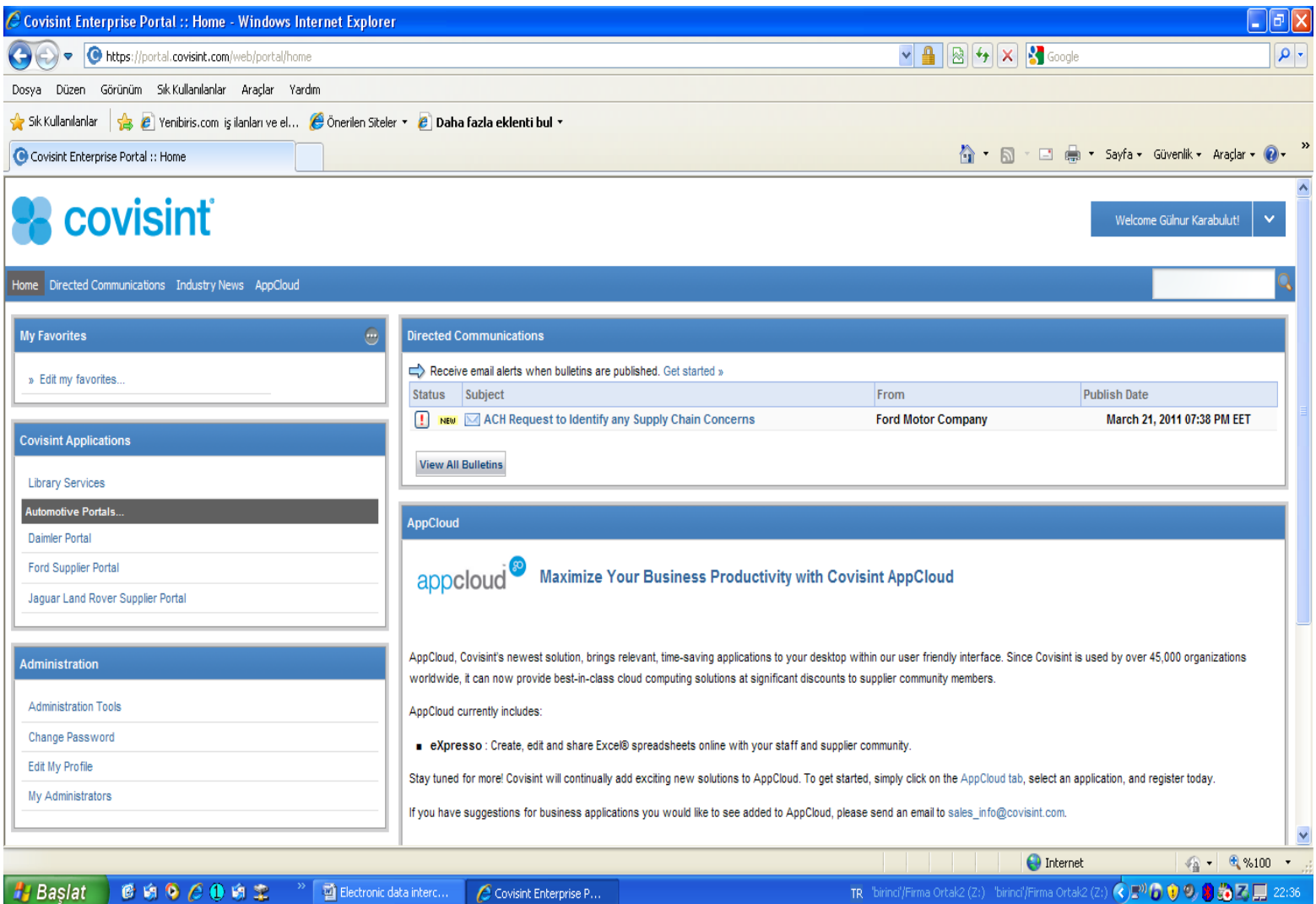

\section{Exhibit 7}

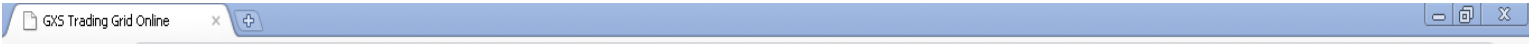

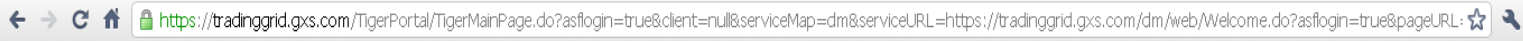

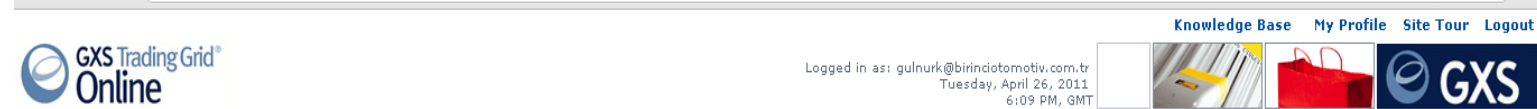

Operations Center Document Manager Account Manager

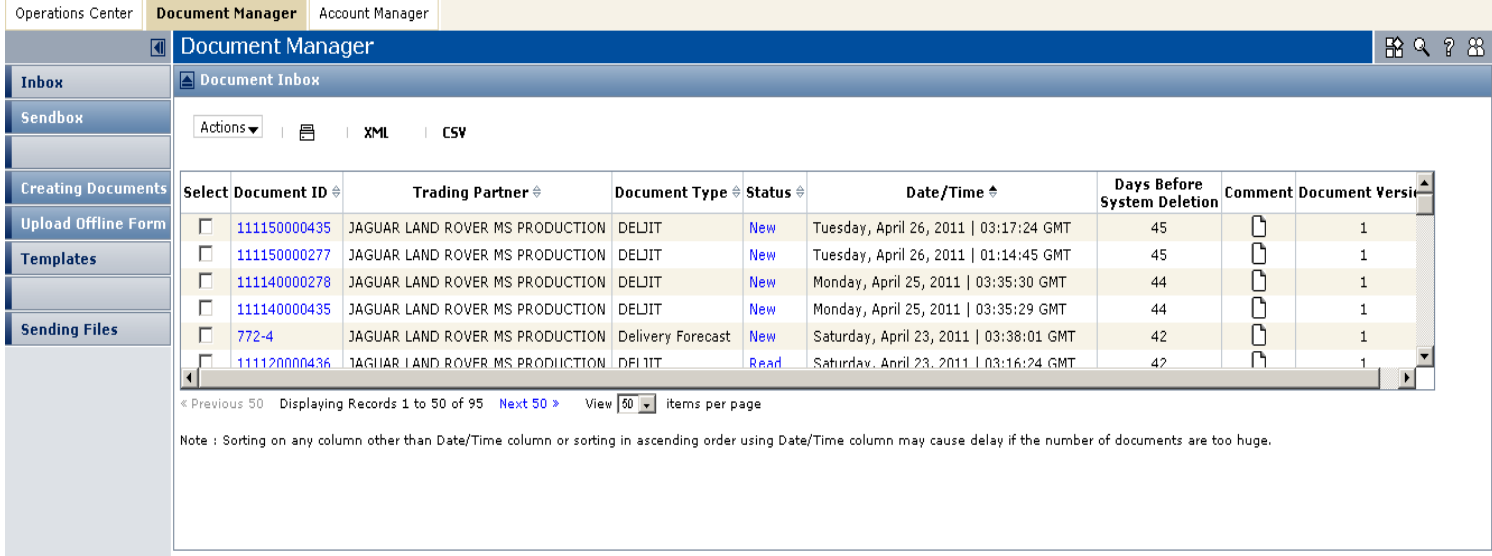

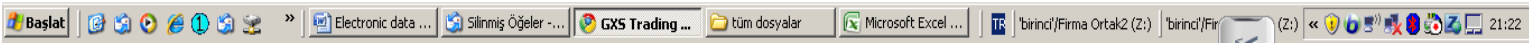

\section{Exhibit 8}

